\title{
Selection of $\mathrm{F}_{3}$ populations of Capsicum annuum for greenhouse production
}

\author{
Laura Raquel Luna García ${ }^{1}$, Valentín Robledo Torres $^{1}{ }^{1}$, Francisca Ramírez Godina ${ }^{2}$, Rosalinda Mendoza \\ Villarreal $^{1}$, Miguel Ángel Pérez Rodríguez ${ }^{3}$
}

\author{
${ }^{1}$ Departamento de Horticultura, de la Universidad Autónoma Agraria Antonio Narro. Calzada Antonio Narro 1923, C. P. \\ 25315. Saltillo, Coahuila, México \\ ${ }^{2}$ Departamento de Fitomejoramiento, de la Universidad Autónoma Agraria Antonio Narro. Calzada Antonio Narro 1923, \\ C. P. 25315. Saltillo, Coahuila, México \\ ${ }^{3}$ Departamento de Botánica de la Universidad Autónoma Agraria Antonio Narro. Calzada Antonio Narro 1923, C. P. \\ 25315. Saltillo, Coahuila, México
}

*Corresponding author: robledo3031@gmail.com

\begin{abstract}
Capsicum annuum is one of the most important plant species in the world. México has the greatest diversity for this plant. However, its production is limited due to the scarcity of improved varieties for greenhouse production. Therefore, the development of high-yield varieties would be possible through the genetic recombination of native varieties (Creole populations) and superior cultivars. Therefore, the purpose of this research work was to assess and select outstanding $F_{3}$ populations for greenhouse production. The work was carried out in a greenhouse at Saltillo, Coahuila Mexico in 2018, involving 8 parents, in which 3 varieties were used as female (pollen-receptor plants), 5 varieties as males (pollen-donor plants) and $9 F_{3}$ populations derived by selfing from $9 F_{2}$ populations. The parents and $F_{3}$ populations composed 17 treatments that were established in a greenhouse under a randomized block design with three replications. The variables were total fruit yield, average fruit weight, total number of fruits per plant, ascorbic acid content, total capsicinoids, days to flowering, days to harvest, final plant height, and basal stem diameter. Significant differences were found in all variables of $F_{3}$ populations. The highest RTF (total fruit weight) belonged to $P_{1,4}$ and $P_{1,6}$, with1647.0 and $1652.0 \mathrm{~g} /$ plant, respectively. In terms of CAA (ascorbic acid content), population $\mathrm{P}_{2,4}$, was significantly superior to the rest of the genotypes and exceeded the best parent by $19.8 \%$. We concluded that populations $P_{1,4}, P_{1,6}$ and $P_{2,4}$ may be uased to develop cultivars with high yield and high quality for greenhouse production.
\end{abstract}

Keywords: Capsicum annuum, transgressive segregation, vitamin C, protected agriculture.

Introduction

The Capsicum annuum species is one of the most important cultivated horticultural species in the world. Mexico is the second leading global producer with 173 thousand hectares. This crop is also a source of 12000 jobs for growers (SIAP, 2018) and provides more than 30 million salaries to day laborers in the agrochemical, transportation, storage and trade industries (Ramírez Meraz et al., 2019). Its great potential is due to its high global consumption, being one of the most widely used condiments in the world. Consumption rate for Asia and the Middle East is $3 \%$ to $4 \%$. Globally, the rate of consumption is $2 \%$ to $3 \%$ per annum (Olatunji and Afolayan, 2018).

More than 2 billion individuals in the world are facing micronutrient deficiencies, such as zinc, iodine, and iron, followed by vitamins. However, hot pepper consumption worldwide can reduce the human micronutrient deficiency. Thus, sufficient amounts of micronutrients can be provided by incorporating the pepper fruit with a common diet that could beneficially help to combat nutrient deficiency (Motukuri and Jaswanthi, 2020). Chili pepper is a source of vitamins (A, $B_{6}, C$ and $\mathrm{E})$, antioxidants, minerals $(\mathrm{K}, \mathrm{P}, \mathrm{Mg}, \mathrm{Ca}, \mathrm{Fe}$,$) and fiber$ (Olatunji and Afolayan, 2018; USDA, 2016) for standard reference release 28 (revised May 2016). It is indispensable for human nutrition and it is raw material for the industrial sector. Despite being the center of origin, Mexico only produces $40 \%$ of the green chili peppers eaten in the country; $60 \%$ come from China (Seva Rivadulla, 2019). Currently, there is a drop in production, which is associated with limited cultivable lands, due to conversion of agricultural lands to urban, degradation and other soil and climatic factors (FAO, 2019). In Mexico, only $15.5 \%$ of the green chili peppers (Jalapeño, Serrano, Poblano, sweet pepper) come from protected agriculture, using bred varieties and sophisticated production technologies (Clausen et al., 2017). To encounter this problem, it is necessary to produce varieties of chili peppers for cultivation in greenhouse, as an alternative to improve productivity in this crop. A more 
efficient use of inputs occurs with the use of improved seeds, considering greater production and fruit quality and costbenefit ratio. Therefore, the development of improved varieties and the use of other technologies are alternatives to improve productivity. The high yield of Capsicum annuum will be guaranteed with the use of improved cultivars and efficient use of water and nutrition (Maraña Santacruz et al., 2018).

A hybridization or pedigree selection-breeding program must ensure proper trait combination and good trait selection to obtain high-quality products (Márquez, 1988). The purpose of this research work was to assess and select $F_{3}$ outstanding populations for greenhouse production.

\section{Results and Discussion}

\section{Yield and yield components}

Parental and $F_{3}$ population analysis presented significant differences $(P<0.01)$ among RTF, NFP and PPF genotypes. Populations $P_{1,4}$ and $P_{1,6}$, had the highest yield per plant, with 1647.0 and $1652.0 \mathrm{~g} /$ plant, respectively, significantly exceeding the parents $(P<0.01)$, creole Mirador, UANs and the populations $P_{2,4}$ and $P_{2,5}$ (Table 2). The estimated yield in these populations was 68.6 and $68.8 \mathrm{t} / \mathrm{ha}$, respectively, although they were significantly equal to the origin. The populations $P_{1,4}$ and $P_{1,6}$ were higher by 34.4 and $34.8 \%$ than their UANj parents and more than $18 \%$ than the paternal parents, with the advantage that the fruit of the populations $P_{1,4}$ and $P_{1,6}$ are of the UANj type, which are considered outstanding. Also $P_{1,4}$ and $P_{1,6}$ populations exceeded the Mexico's average production by 333\%, which reached 20.6 t/ha in 2019 (SIAP, 2019). García et al. (2014) obtained 55 t/ha of jalapeño chili pepper yield, while García Sandoval et al. (2016) obtained only $38 \mathrm{t} /$ ha. Populations $\mathrm{P}_{1,4}$ and $\mathrm{P}_{1,6}$, exceeded $25 \%$ up to $80 \%$ the production obtained in previous research works. Maximum yield reported in Mexico for Jalapeño chili pepper Mitla variety, grown under greenhouse conditions, was $65.2 \mathrm{t} / \mathrm{ha}$ (Duarte et al., 2012), which is lower than the yield obtained in this research work.

Creole Mirador (parent) showed the highest NFP (61.6), although it was equal $(P \leq 0.05)$ to maternal parents. However, PPF was $8.9 \mathrm{~g}$. Therefore, it does not have significant influence on RTF. This coincides with the results reported by Cebula (1995), who mentioned that some hybrids with high NFP were smaller. These fruits reached smaller size (length and width), as they are the product of a highest fruit-set. Female parents were significantly different $(P \leq 0.05)$ from male parents in terms of NFP, obtaining an average of 10.14; although other research works obtained NFP of 7 to 11.8 (Moreno-Pérez et al., 2011).

UANCn genotype had the highest PPF, which was equal to UANRd and UANSHw and higher than the PPF of $F_{3}$ populations, which ranged between 21.8 and $55 \mathrm{~g}$. The $P_{1,4}$ and $P_{1,5}$ populations were significantly superior than the female parents. In this research, the selection process focused on fruit development, with traits similar to UANj type. Therefore, the PPF of $F_{3}$ is between twice the weight of the female parents and $50 \%$ the weight of male parents, enabling to take advantage of additive genetic variance (Suryakumari et al., 2010).

Maternal parents had a PPF of $15.4 \mathrm{~g}$, matching the results reported by Ramírez Meraz et al. (2019) in Serrano hybrids with a PPF between 9 and $14 \mathrm{~g}$. $F_{3}$ populations had $36.4 \mathrm{~g}$, coinciding with the results of García Sandoval et al. (2016), who found that $68 \%$ of the Jalapeño chili pepper lines in their research work exceeded $30 \mathrm{~g}$. $\mathrm{P}_{1,4}$ and $\mathrm{P}_{1,5}$ UANj populations had the highest PPF, 55 and $52.7 \mathrm{~g}$, respectively; which is attributed to the interaction and gene recombination of the parental populations and the preservation of such trait by phenotypic selection.

\section{Fruit quality}

In CAA and CAPs variables, we found significant differences among parents and $F_{3}$ populations $(P \leq 0.01)$. Table 3 shows that parents $P_{6}$ and $P_{7}$ had higher CAAs and were significantly higher than the rest of the male and female parents. The $P_{1,5}$ and $P_{1,7}$ populations of $F_{3}$ were significantly equal to four male progenitors in CAA. However, $P_{2,4}$ population was significantly superior among all the genotypes, with $224.9 \mathrm{mg} / 100 \mathrm{~g}$; and $19.8 \%$ more CAA than the best parent, showing a gene interaction that fosters the overexpression of this trait. CAA of $P_{2,4}$ population was superior in terms of CAA than 30 collections of Guajillo chili pepper form Durango and Zacatecas, Mexico (Martínez-Damián et al., 2019).

On the other hand, Cares et al. (2015) reported a CAA in pepper ranging between 274.3 and $355.5 \mathrm{mg} / 100 \mathrm{~g}$, values which are significantly higher than those found in this research. It is known that CAA in Capsicum species is widely affected by environmental factors, such as high temperatures, salinity, biotic factors, or nutritional factors. Preciado-Rangel et al. (2019) indicated that an increase in $K$ in the nutrient solution increases vitamin $C$ content in Serrano chili pepper. Therefore, knowledge on the genotype-environment interaction can be used in breeding programs to obtain fruits with high CAA content, in order to improve nutrition. The CAA is an essential antioxidant, capable of neutralizing free radicals, regenerate vitamin $\mathrm{E}$ and act as a co-factor of $\alpha$-ketoglutaratedependent dioxygenase enzymes (Villagrán et al., 2019). Daily recommended vitamin $C$ intake requirements range from 75 to $90 \mathrm{mg} /$ day (Valdez, 2006). This information is important for backcross breeding programs that can help increasing the values of this antioxidant and produce high-yielding crops with nutraceutical quality.

UANs chili pepper was significantly superior to the rest of the genotypes in terms of CAPs content, followed by UANj and Creole Mirador, which exceeded significantly the male parents and $F_{3}$ populations. Male parents were significantly equal and had the least CAPs content, while a wide variability was showed in CAPs of $F_{3}$ populations, with a range 6361.4 to 10264.9 SHU. The population $P_{3,8}(10264.9 \mathrm{SHU})$ and $P_{1.4}$ ( $9716.6 \mathrm{SHU}$ ) had the highest CAPs but were statistically equal. Maternal parents had an average of $13590.9 \mathrm{SHU}$, the fathers had 776.4 and $F_{3}$ populations had $7183.7 \mathrm{SHU}$, outstanding $P_{3,8}$ genotype with 10,264.9 SHU.

In Capsicum there are different levels of itching characteristic that is determined by genetic, environmental and geneticenvironmental interaction factors. Therefore, the conditions of management of chili cultivation also affect the content of capsaicinoids (Garcés-Claver et al., 2007). On the other hand, Rostini et al. (2019) stated that Capsaicin is a polygenic inherited trait, controlled by four pairs of genes that affect 
Table 1. Parents and F3 populations used in this research work.

\begin{tabular}{|c|c|c|}
\hline Genotypes & Description & \\
\hline \multicolumn{3}{|l|}{ Female parents } \\
\hline UANj & & $\begin{array}{l}\text { Spicy fruit, } 6 \text { to } 8 \mathrm{~cm} \text { in length and diameter of } 2.5 \text { to } 3 \\
\mathrm{~cm}\end{array}$ \\
\hline Creole mirador & & $\begin{array}{l}\text { Spicy fruit, } 4 \text { to } 6 \mathrm{~cm} \text { in length and diameter of } 1.8 \text { to } \\
2.3 \mathrm{~cm}\end{array}$ \\
\hline UANs & & $\begin{array}{l}\text { Spicy fruit, } 5.8 \text { to } 6 \mathrm{~cm} \text { in length and diameter of } 1.9 \text { to } \\
2.0 \mathrm{~cm}\end{array}$ \\
\hline \multicolumn{3}{|l|}{ Male parents } \\
\hline UANOg & & $\begin{array}{l}\text { Sweet pepper, } 8.5 \text { to } 8.6 \mathrm{~cm} \text { in length and diameter of } \\
8.2 \text { to } 8.4 \mathrm{~cm}\end{array}$ \\
\hline UANRd & & $\begin{array}{l}\text { Sweet pepper, } 8.5 \text { to } 8.6 \mathrm{~cm} \text { in length and diameter of } \\
8.2 \text { to } 8.4 \mathrm{~cm}\end{array}$ \\
\hline UANShw & & $\begin{array}{l}\text { Sweet pepper, } 10 \text { to } 12 \mathrm{~cm} \text { in length and diameter of } \\
8.2 \text { to } 8.6 \mathrm{~cm}\end{array}$ \\
\hline UANYw & & $\begin{array}{l}\text { Sweet pepper, } 6.5 \text { to } 7.0 \mathrm{~cm} \text { in length and diameter of } \\
7.9 \text { to } 8.0 \mathrm{~cm}\end{array}$ \\
\hline UANCn & & $\begin{array}{l}\text { Sweet pepper, } 8.0 \text { to } 8.2 \mathrm{~cm} \text { in length and diameter of } \\
8.9 \text { to } 9.0 \mathrm{~cm}\end{array}$ \\
\hline $\mathrm{F}_{3}$ populations & F3 origin & \\
\hline $\mathrm{P}_{1,4}$ & UANj $\times$ UAN & \\
\hline$P_{1,5}$ & UANj x UAN & \\
\hline$P_{1,6}$ & UANj $\times$ UAN & \\
\hline$P_{1,7}$ & UANj x UAN & \\
\hline$P_{2,4}^{1,}$ & Creole Mira & g Crossing \\
\hline$P_{2,5}$ & Creole Mira & d Crossing \\
\hline$P_{2,6}$ & Creole Mira & Hw Crossing \\
\hline$P_{3,4}$ & UANs $x$ UAN & \\
\hline$P_{3,8}$ & UANs $x$ UAN & \\
\hline
\end{tabular}

Table 2. Mean yield values and yield components in Capsicum annuum parents and $\mathrm{F}_{3}$ populations.

\begin{tabular}{lccc}
\hline Genotypes & $\begin{array}{c}\text { Total fruit yield } \\
\text { g/plant }\end{array}$ & $\begin{array}{c}\text { Fruit } \\
\text { per plant }\end{array}$ & $\begin{array}{c}\text { Average fruit weight } \\
\mathrm{g}\end{array}$ \\
\hline P1.-UANj & $1225.2 \mathrm{abc}$ & $56.6 \mathrm{ab}$ & $23.2 \mathrm{de}$ \\
P2.-Creole mirador & $552.3 \mathrm{e}$ & $61.6 \mathrm{a}$ & $8.9 \mathrm{e}$ \\
P3.-UANs & $678.6 \mathrm{bcde}$ & $48.3 \mathrm{abc}$ & $14.1 \mathrm{de}$ \\
P4.-UANOg & $1395.0 \mathrm{ab}$ & $11.4 \mathrm{fg}$ & $123.0 \mathrm{~b}$ \\
P5.-UANRd & $1240.5 \mathrm{abc}$ & $8.7 \mathrm{~g}$ & $131.6 \mathrm{ab}$ \\
P6.-UANShw & $1329.6 \mathrm{ab}$ & $11.7 \mathrm{fg}$ & $127.8 \mathrm{ab}$ \\
P7.-UANYw & $1243.9 \mathrm{abc}$ & $10.4 \mathrm{~g}$ & $123.8 \mathrm{~b}$ \\
P8.-UANCn & $1247.1 \mathrm{abc}$ & $8.5 \mathrm{~g}$ & $153.6 \mathrm{a}$ \\
P1,4 & $1647.0 \mathrm{a}$ & $29.6 \mathrm{de}$ & $55.0 \mathrm{c}$ \\
P1,5 & $1487.2 \mathrm{ab}$ & $29.3 \mathrm{de}$ & $52.7 \mathrm{c}$ \\
P1,6 & $1652.0 \mathrm{a}$ & $43.2 \mathrm{bcde}$ & $35.6 \mathrm{cde}$ \\
P1,7 & $1301.5 \mathrm{ab}$ & $34.5 \mathrm{cde}$ & $41.2 \mathrm{~cd}$ \\
P2,4 & $609.9 \mathrm{de}$ & $27.5 \mathrm{ef}$ & $22.3 \mathrm{de}$ \\
P2,5 & $860.9 \mathrm{bcde}$ & $39.0 \mathrm{cde}$ & $21.8 \mathrm{de}$ \\
P2,6 & $1239.8 \mathrm{abc}$ & $43.7 \mathrm{bcd}$ & $28.6 \mathrm{cde}$ \\
P3,4 & $1205.8 \mathrm{abc}$ & $32.2 \mathrm{cde}$ & $32.9 \mathrm{cde}$ \\
P3,8 & $1177.1 \mathrm{abcd}$ & $30.5 \mathrm{de}$ & $37.8 \mathrm{~cd}$ \\
\hline DMS & 584.15 & 16.16 & 28.25 \\
\hline DMS & &
\end{tabular}


Table 3. Mean values of quality in Capsicum annuum parents and $F_{3}$ populations.

\begin{tabular}{lcc}
\hline Genotypes & $\begin{array}{c}\text { Ascorbic acid content } \\
\mathrm{mg} / 100 \mathrm{~g}\end{array}$ & $\begin{array}{c}\text { Capsaicinoids } \\
\text { SHU }\end{array}$ \\
\hline P1.-UANj & $88.7 \mathrm{ef}$ & $12645.9 \mathrm{~b}^{*}$ \\
P2.-Creole Mirador & $90.6 \mathrm{ef}$ & $12936.4 \mathrm{~b}$ \\
P3.-UANs & $113.9 \mathrm{de}$ & $15190.6 \mathrm{a}$ \\
P4.-UANOg & $140.7 \mathrm{~cd}$ & $965.7 \mathrm{i}$ \\
P5.-UANRd & $144.2 \mathrm{~cd}$ & $849.4 \mathrm{i}$ \\
P6.-UANShw & $187.7 \mathrm{~b}$ & $763.8 \mathrm{i}$ \\
P7.-UANYw & $157.6 \mathrm{bc}$ & $635.2 \mathrm{i}$ \\
P8.-UANCn & $136.3 \mathrm{~cd}$ & $668.0 \mathrm{i}$ \\
P1,4 & $77.8 \mathrm{fg}$ & $9716.6 \mathrm{~cd}$ \\
P1,5 & $124.4 \mathrm{~cd}$ & $8083.7 \mathrm{ef}$ \\
P1,6 & $67.7 \mathrm{fg}$ & $6361.4 \mathrm{~g}$ \\
P1,7 & $127.9 \mathrm{~cd}$ & $7264.3 \mathrm{fg}$ \\
P2,4 & $224.9 \mathrm{a}$ & $7966.6 \mathrm{ef}$ \\
P2,5 & $50.6 \mathrm{~g}$ & $4634.9 \mathrm{~h}$ \\
P2,6 & $62.4 \mathrm{fg}$ & $7774.7 \mathrm{ef}$ \\
P3,4 & $46.4 \mathrm{~g}$ & $8652.7 \mathrm{de}$ \\
P3,8 & $60.5 \mathrm{fg}$ & $10264.9 \mathrm{c}$ \\
\hline DMS & 33.46 & 1065.7 \\
\hline
\end{tabular}

DMS= minimum significant difference; ${ }^{*}$ values followed by the same letter are not statistically different, SHU = Scoville units.

Table 4. Mean values of precocity in Capsicum annuum parents and $F_{3}$ populations.

\begin{tabular}{lcc}
\hline Parents & Days to flowering & $\begin{array}{c}\text { Days to } \\
\text { harvest }\end{array}$ \\
\hline P1-UANj & $61.6 \mathrm{bc}^{*}$ & $149.0 \mathrm{a} *$ \\
P2.-Creole Mirador & $81.1 \mathrm{a}$ & $114.1 \mathrm{~cd}$ \\
P3.-UANs & $54.0 \mathrm{bcd}$ & $129.5 \mathrm{abc}$ \\
P4.-UANOg & $60.2 \mathrm{bc}$ & $141.0 \mathrm{ab}$ \\
P5.-UANRd & $59.0 \mathrm{bc}$ & $96.7 \mathrm{~d}$ \\
P6.-UANShw & $61.9 \mathrm{~b}$ & $128.1 \mathrm{abc}$ \\
P7.-UANYw & $51.6 \mathrm{cde}$ & $109.6 \mathrm{~cd}$ \\
P8.-UANCn & $49.1 \mathrm{def}$ & $110.9 \mathrm{~cd}$ \\
P1,4 & $36.2 \mathrm{gh}$ & $110.0 \mathrm{~cd}$ \\
P1,5 & $31.2 \mathrm{~h}$ & $105.0 \mathrm{~cd}$ \\
P1,6 & $31.7 \mathrm{~h}$ & $119.8 \mathrm{bcd}$ \\
P1,7 & $31.6 \mathrm{~h}$ & $107.4 \mathrm{~cd}$ \\
P2,4 & $34.3 \mathrm{gh}$ & $104.9 \mathrm{~cd}$ \\
P2,5 & $39.0 \mathrm{fgh}$ & $109.5 \mathrm{~cd}$ \\
P2,6 & $30.4 \mathrm{~h}$ & $106.3 \mathrm{~cd}$ \\
P3,4 & $42.1 \mathrm{efg}$ & $119.0 \mathrm{bcd}$ \\
P3,8 & $37.0 \mathrm{gh}$ & $118.9 \mathrm{bcd}$ \\
\hline DMS & 10.14 & 25.51 \\
\hline DMS= minimum significant difference; *values followed by the same letter are not statistically different & &
\end{tabular}

Table 5. Mean values of agronomic variables in parents and $F_{3}$ populations of Capsicum annuum.

\begin{tabular}{lll}
\hline Genotype & $\begin{array}{l}\text { ADP } \\
\mathrm{cm}\end{array}$ & $\begin{array}{l}\text { DBT } \\
\mathrm{mm}\end{array}$ \\
\hline P1. UANj & $53.4 \mathrm{~g}$ & $11.5 \mathrm{def}$ \\
P2.Creole Mirador & $65.0 \mathrm{fg}$ & $8.3 \mathrm{f}$ \\
P3. UANs & $100.3 \mathrm{def}$ & $11.4 \mathrm{def}$ \\
P4. UANOg & $82.8 \mathrm{efg}$ & $23.7 \mathrm{ab}$ \\
P5. UANRd & $53.3 \mathrm{~g}$ & $18.5 \mathrm{bcd}$ \\
P6. UANShw & $70.7 \mathrm{efg}$ & $18.2 \mathrm{bcde}$ \\
P7. UANYw & $56.3 \mathrm{~g}$ & $21.8 \mathrm{abc}$ \\
P8. UANCn & $50.7 \mathrm{~g}$ & $20.4 \mathrm{bc}$ \\
P1,4 & $155.5 \mathrm{abc}$ & $18.2 \mathrm{bcde}$ \\
P1,5 & $124.9 \mathrm{~cd}$ & $19.8 \mathrm{bcd}$ \\
P1,6 & $167.5 \mathrm{ab}$ & $19.3 \mathrm{bcd}$ \\
P1,7 & $110.3 \mathrm{de}$ & $20.7 \mathrm{abc}$ \\
P2,4 & $77.5 \mathrm{efg}$ & $9.7 \mathrm{ef}$ \\
P2,5 & $78.1 \mathrm{efg}$ & $14.2 \mathrm{cdef}$ \\
P2,6 & $124.1 \mathrm{~cd}$ & $19.6 \mathrm{bcd}$ \\
P3,4 & $175.1 \mathrm{a}$ & $29.2 \mathrm{a}$ \\
P3,8 & $136.1 \mathrm{bcd}$ & $23.7 \mathrm{ab}$ \\
\hline DMS & 37.12 & 8.56 \\
CV & 12.2 & 15.3 \\
\hline
\end{tabular}

$\mathrm{ADP}=$ The final plant height: $\mathrm{DBT}=$ basal stem diameter; $\mathrm{DMS}=$ minimum significant difference; $\mathrm{CV}=$ Variation coefficient; ${ }^{*}$ values followed by the same letter are not statistically different. 
CAPs' synthesis pathways in a differential way, due to the expression levels of involved genes. This information is quite important to breed this plant species.

\section{Precocity}

Precocity is important, because it enables earlier harvesting and thereby lower production costs, especially when capsicum is grown in greenhouse, which is very input demanding system. There were significant differences $(P \leq 0.01)$ in $D A F$ and $D A C$ among parents and $F_{3}$ populations. In $\mathrm{DAF}$, there was a range of 49.1 to 81d, with an average of 59.8 days, showing variability among the parents. The later was Mirador, while the most early was UANcn with significant difference. However, in $F_{3}$ populations, the range of DAF was 30.4 (P2.6) to 42.1 (P3.4), with an average of 34.8 days. Population $P_{2,6}$ had the highest precocity (30.4 DAF). This is important, because the DAF difference between parents and their offspring was 25 days (Table 4). Therefore, we can infer that DAF reduction in $F_{3}$ populations is due to the transgressive segregation of this trait. The transgressive segregation is referred to genetic recombination in generations after F1. Therefore, we can conclude that DAF is a polygenic trait and can be reduced by selection without reducing yield.

We found significant differences $(P \leq 0.01)$ among the genotypes in terms of DAC. UANj was the latest (149 DAC), although it was significantly equal to UANs. Female parents were later with an average of 130.8 days. Male parents UANOg (141 DAC) and UANShw (128.1 DAC) were the latest and significantly equal, while different to UANRd $(P \leq 0.01)(96.7$ $D A C)$. This parent was significantly equal to $F_{3}$ populations, with an average of 111.2 DAC. $P_{2,4}$ and $P_{1,5}$ populations were earlier similar to Jalapeño chili pepper commercial varieties, Don Benito, Don Pancho and Kohunlich that were harvested 110 after transplanting (Ramírez Meraz et al., 2015). DAC variable showed transgressive heritage, since the average number of days required by populations $P_{1,4}$ and $P_{1.6}$ were lower than the DAC of the parents.

\section{Agronomic variables}

Among parents and $F_{3}$ populations, there were significant differences $(P \leq 0.01)$ in ADP and DBT. Table 5 shows that in $F_{3}$ population, $P_{3.4}$ had higher $\operatorname{ADP}(175.1) \mathrm{cm}$, although it was significantly equal to populations $P_{1.6}(167.5 \mathrm{~cm})$ and $P_{1.4}$ $(155.5 \mathrm{~cm})$, while significantly exceeded $(P \leq 0.01)$ all other populations and parents. In greenhouse crops, the ADP variable is important to take advantage of the higher airconditioned environmental volume inside the greenhouse prolonging the production cycle. $F_{3}$ populations exhibited higher ADP with an average of $127.67 \mathrm{~cm}$, while maternal parents $72.9 \mathrm{~cm}$ and paternal parents $62.7 \mathrm{~cm}$. $F_{3}$ populations exceeded the average maternal progenitors by $75.1 \%$ and by $103.6 \%$ female parents. This is important since the plant with continuous growth, maintains flower production for longer (Aguilar-Delgado et al., 2018) time increasing the production cycle.

The $F_{3}, P_{3,4}$ population had the highest DBT $(29.2 \mathrm{~mm})$ but was significantly equal to $F_{3}$ populations $\left(P_{3.8}\right.$ and $\left.P_{1.7}\right)$ and paternal parents $\left(P_{4}\right.$ and $\left.P_{7}\right)$. Stem diameter is important, since along with the higher DBT, there is greater capacity to support the weight of branches, leaves, flowers and fruits. Therefore, the risk of rupture of the aerial part of the plant will be lower
(Elizondo-Cabalceta and Monge-Pérez, 2016). On the other hand, Cankaya et al. (2010) indicated that both ADP and DBT are significantly related to RTF per plant and that this variable should be used with the aim of increasing yield per plant in pepper populations. In sweet chilli, the diameter of the stem ranges from 14.0 to $27.3 \mathrm{~mm}$ (Moreno et al., 2011; ReséndizMelgar et al., 2010). Parent Mirador has a thin, low and fragile stem that limits high production in greenhouse. Tis genotype did not develop properly, even in controlled environment conditions with optimal irrigation and nutrition. However, some $F_{3}$ populations derived from Mirador exhibited outstanding yield characteristics $\left(P_{2,6}\right)$ and fruit quality $\left(P_{2,4}\right)$.

\section{Materials and Methods}

\section{Location}

This research work took place at "Universidad Autónoma Agraria Antonio Narro" (UAAAN) in Saltillo, Coahuila, Mexico, located at $25^{\circ} 21^{\prime} 19^{\prime \prime}$ North latitude, 101 01'48" West longitude ("Servicio Meteorológico Nacional"-National Weather Service, 2018).

\section{Plant materials}

Four types of Capsicum annuum were studied (Jalapeño, Mirador, Serrano and sweet pepper selected at UAAAN). The study included the original parents ( 3 females and 5 males) and $9 F_{3}$ offspring populations from derived from parental crossings (Table 1 ).

To obtain the $F_{3}$ populations, the following procedure was carried out in a greenhouse.

1- three varieties of hot chili (1- Jalapeño, 2- Mirador, 3Serrano) were selected as females and five varieties of pepper (4- UANOg, 5- UANRd, 6- UANShw, 7- UANYw, 8- UANCn) that were used as males.

2- By manually crossing the females with the males, only nine $F_{1}$ hybrids were obtained (Table 1 ).

3- In each of the $F_{1}$ populations, self-fertilization was allowed in a natural way and the best plants were selected, from which the seeds that showed higher characteristics over nine populations were obtained.

4- In the $F_{2}$ populations, natural self-fertilization is again included and the best plants from each $F_{2}$ populations were selected to form nine $F_{3}$ populations.

\section{Establishment and management of parents and $F_{3}$ populations}

Parental seeds and $F_{3}$ populations were sown in 200-cavity polystyrene trays. The substrate was peat (Premier Sphagnum Peat Moss, Angeles Millwork \& Lumber Co.) and mineral perlite (Termolita by Hortiperl) in a 70:30 ratio, respectively. Transplantation took place 50 days after planting, establishing 12 plants per plot in $25 \mathrm{~cm}$-high $\times 1.60 \mathrm{~m}$-wide beds, with white plastic mulching, subsurface drip irrigation, leaving 30 centimeters between plants, staggered at double row with double-stem pruning and with Dutch type tutored. Plants received drip irrigation at a rate of $0.5 \mathrm{~L} /$ plant/day until blooming, gradually increasing to $3 \mathrm{~L} / \mathrm{plant} / \mathrm{day}$ at full production. Nutrition (Steiner, 1984) was applied with the irrigation water according to the crop's developmental stage (15\% seedling, 25\% growth; 50\% development, 75\% flowering and $100 \%$ fruit filling and harvest). 
The crop was established under a fully randomized experimental block design with three replicates. Irrigation was applied every third day, with preventive control every 15 days, using active ingredients such as Imidacloprid, abamectin, thiamethoxam and chlorpyrifos against Bemisia tabaci, Bactericera cockerelli, Lirimyza sp.

\section{Yield and yield components}

Total fruit weight (RTF) (g/plant) was estimated by weighing all the fruits from 6 plants per treatment in every harvest, using Ohaus Compass ${ }^{\mathrm{T}} \mathrm{CX}$ electronic scale. We added the weights before dividing them by the number of plants and the number of cuts. We divided RTF by the number of harvested fruits to estimate average fruit weight (PPF). The number of fruits per plant (NFP) was estimated by counting all the fruits that were harvested throughout the crop season divided by the six harvested plants.

\section{Fruit quality measurements}

Fruit quality was determined in three fresh fruits per treatment in every replicate of the fifth harvest. Ascorbic acid content (CAA) of the fruits was estimated using AOAC (2000) color-change titration methodology, with $100 \mathrm{~g}$ of fruit per treatment.

Capsaicinoids (CAPs) were quantified by Bennet \& Kirby method (1968), using physiologically mature fruits and a Bio145025 BIOMATE-5 spectrophotometer (Thermo Electron Corporation, Madison, USA) at $286 \mathrm{~nm}$ wavelength. In order to estimate CAPs, we built a calibration curve of this compound (Sigma, Co.), within 0 to $1.2 \mathrm{mg} / \mathrm{ml}$ range. CAPs content of every sample was triple-folded, expressed in Scoville units, (SHU).

\section{Precocity measurements}

Days to flowering (DAF) and days to harvest (DAC) were determined by counting the days from transplant until every plant had its first flower, and until harvesting the first fruit from every plant. We left ten days between harvests and there were nine harvests within 80 days.

\section{Estimation of agronomic variables}

The final plant height (ADP) was measured with a tape measure, from the base to the apex of the plant at the end of the production cycle ( 85 days after the first cut). The basal stem diameter (DBT) was measured at $3 \mathrm{~cm}$ above the floor surface with an Autotec brand digital vernier.

\section{Variance analysis}

All the variables subjected to variance analysis and Tukey's mean comparison test $(\mathrm{P} \leq 0.01)$ using $\mathrm{SAS}^{\circledR}$ V.9.0 (SAS Institute Inc., 2002) statistical program.

\section{Conclusions}

$\mathrm{F}_{3}$ populations showed transgressive segregation resulting from the genetic recombination of previous generations. The selection can be efficiently used to breed high-yield chili pepper cultivars and quality for greenhouse production. Intercrossing enabled genetic recombination and the expression of high -phenotypic variability in yield, yield components, fruit quality and precocity. Populations $P_{1,4}$ and
$P_{1,6}$, were the most promising candidates to backcrossing breeding due to their precocity and high yields. Furthermore, population $\mathrm{P}_{2,4}$, showed higher ascorbic acid content.

\section{Acknowledgments}

We thanks to the National Council for Science and Technology (CONACYT), for the graduate student's scholarship and to the Universidad Autónoma Agraria Antonio Narro (UAAAN).

\section{References}

Aguilar-Delgado M. J, Acosta-García G, Espitia-Rangel E, González-Chavira MM, Lozano-Sotomayor P, Folter SD, Guevara-Olvera L (2018) Crecimiento indeterminado y determinado en Amaranthus hypochondriacus: ontogenia del meristemo apical y efecto sobre el peso de semilla. Agrociencia. 52(5): 695-711.

AOAC (2000). Official Methods of Analysis of AOAC International. No. C/630.240 03/2000.

Bennett DJ, Kirby GW (1968) Constitution and biosynthesis of Capsici. J Chem Soc C: Organic. 442-446.

Cankaya S, Balkaya A, Karaagac O (2010) Canonical correlation analysis for the determination of relationships between plant characters and yield components in red pepper [Capsicum annuum L.var. conoides (Mill.) Irish] genotype. Span J Agric Res. 8(1): 67-73.

Cares IEF, Damián MTM, Pérez JER, Álvarez OC, León MTBC, Guadarrama SV, Ramírez SPR (2015) Capacidad antioxidante en variedades de pimiento morrón (Capsicum annuum L.). Interciencia. 40(10): 696-703.

Cebula E (1995) Optimization of plant and shoot spacing in greenhouse production of sweet pepper. Acta Hortic. 412:321-329.

Clausen AM, Ferrer M, Atencio HM, Menéndez-Sevillano MDC, Formica MB, Defacio R, Rosso BS (2017) Conservación, utilización y acceso a recursos fitogenéticos de importancia para la agricultura y la alimentación. Nexos. 23(31): 5-9.

Duarte RM, Contreras RLG, Contreras FR (2012) Respuesta de la aplicación de estiércol y fertilizantes sobre el rendimiento y calidad del chile Jalapeño. Biotecnia. 14: 32-38.

Elizondo-Cabalceta E, Monge-Pérez JE (2016) Caracterización morfológica de 12 genotipos de chile dulce (Capsicum annuum L.) cultivados en invernadero en Costa Rica. Rev Tec en Marcha. 29(3): 60-72.

FAO (Organización de las Naciones Unidas para la Agricultura y la Alimentación 2019) http://www.fao.org/3/y3557s/y3557s08.htm

Garcés-Claver A, Gil-Ortega R, Álvarez-Fernández A, ArnedoAndrés MS (2007) Inheritance of capsaicin and dihydrocapsaicin, determined by HPLC-ESI/MS, in an intraspecific cross of Capsicum annuum L.J Agric Food Chem. 55(17): 6951-6957.

García SJA, Nava PRJ y Ramírez MM (2014) Avance productivo de líneas promisorias de chile jalapeño bajo condiciones de temporal y siembra directa en Quintana Roo, México. 11a Convención Mundial del Chile, celebrada del 2 al 4 de octubre de 2014, Morelia, Michoacán, México. p 52-61.

García-Sandoval JA, Meraz M (2016) Rendimiento y calidad de la producción de líneas avanzadas de chile jalapeño (Capsicum annuum) en Quintana Roo. In: Martínez-Herrera J, 
Ramírez-Guillermo MA, Cámara-Córdova J (ed) Innovación Tecnológica para la Seguridad Alimentaria, 1a ed. UJAT: INIFAP, Villahermosa, Tabasco, México. p 203-207.

Maraña-Santacruz JÁ, Castellanos-Pérez E, Vázquez-Vázquez C, Martínez-Ríos JJ, Trejo-Escareño H. I., Gallegos-Robles M. Á, Orona-Castillo I (2018) Rendimiento de chile jalapeño con lixiviado de lombriz con dos métodos de riego. Terra Latinoamericana. 36(4): 345-354.

Márquez SF (1988) Genotecnia Vegetal Tomo II. AGT Editor. México. p. 585-590.

Martínez-Damián MT, Cruz-Álvarez O, Moreno-Pérez EC, ValleGuadarrama S (2019) Intensidad de color y compuestos bioactivos en colectas de chile guajillo del norte de México. Rev Mex Cien Agríc. 10(1):35-49.

Moreno-Pérez EC, Mora-Aguilar R, Sánchez-Castillo F, GarcíaPérez V (2011) Fenología y rendimiento de híbridos de pimiento morrón (Capsicum annuum L.) cultivados en hidroponía. Rev Chapingo Ser Hort. 17(2): 5-18.

Motukuri SK, Jaswanthi N (2020) Hot Pepper (Capsicum annuum L.): An alternative food to reduce micronutrient deficiencies in human. In: Capsicum. A. Dekebo (ed) IntechOpen. DOI:10.5772/intechopen.92198

Olatunji TL, Afolayan AJ (2018) The suitability of chili pepper (Capsicum annuum L.) for alleviating human micronutrient dietary deficiencies: A review. Food Sci Nutrition. 1-13. DOI: 10.1002/fsn3.790

Preciado-Rangel $P$, Andrade-Sifuentes A, Sánchez-Chávez E, Salas-Pérez L, Fortis-Hernández M, Rueda-Puente EO, GarcíaHernández JL (2019) Potassium influence the nutraceutical and antioxidant content of serrano hot pepper (Capsicum annuum L.). Agrociencia. 53: 581-591.

Ramírez-Meraz M, Arcos-Cavazos G, Mata-Vázquez H, Vázquez-García E, Méndez-Aguilar R (2015) Variedades e híbridos de chile y su manejo para el sur de Tamaulipas. Campo Experimental Las Huastecas. Folleto Técnico No. MX0-310701-11-03-14-09-40. $48 \mathrm{p}$

Ramírez-Meraz M, Arcos-Cavazos G, Méndez-Aguilar R, Meneses-Márquez I (2019) Variedades e híbridos de chile para el trópico de México. In: Producción Agropecuaria: Un enfoque integrado. México. p. 29-37. ISBN: 978-607-985431-7
Reséndiz-Melgar RC, Moreno-Pérez EC, Sánchez-DelCastillo F, Rodríguez-Pérez JE, Peña-Lomelí A (2010) Variedades de pimiento morrón manejadas con despunte temprano en dos densidades de población. Rev Chapingo Ser Hort.16 (3):223229.

Rostini N, Fitry-Yenny R, Anas H, Amien S (2019) Inheritance pattern of capsaicin content of Indonesian chili landraces (Capsicum annuum L.). IOP Conference Series: Earth Environ. Sci. 334: 1-5.

SAS Institute (2002) User's Guide of SAS (Statistical Analysis System). SAS Institute Inc. Cary, N. C. USA. $550 p$

Servicio de Información Agroalimentaria y Pesquera (SIAP, 2018 y 2019). http://infosiap.siap.gob.mx:8080/agricola_siap_gobmx/Avan ceNacionalSinPrograma.do

Servicio Meteorológico Nacional SMN. (2018) https://smn.conagua.gob.mx/es/

Seva Rivadulla F (2019) Arrebata China la producción de chile en México. Revista Digital de Productores de Hortalizas en https://www.hortalizas.com/cultivos/chiles-

pimientos/arrebata-chhina-la-produccion-del-chile-enmexico/

Steiner-Abram A (1984) The universal nutrient solution. In: Proc. 6th International Congress on Soilless Culture. Wageningen, The Netherlands. Pp.633-650.

Suryakumari S, Uma-Jyothi K, Srihari D, Sankar AS, Sankar CR (2010) Variability and genetic divergence in paprika (Capsicum annuum L.). J Spices Aromatic Crops.19: 71-75.

United States Department of Agriculture (USDA) (2019) National Nutrient Database for standard reference release 28 (revised april 2019).

Valdés F (2006) Vitamina C. Actas Dermo-Sifiliográficas. 97(9): 557-568.

Villagrán M, Muñoz M, Díaz F, Troncoso C, Celis-Morales C, Mardones L (2019) Una mirada actual de la vitamina $C$ en salud y enfermedad. Rev Chilena de Nutrición, 46(6): 800808. 